\title{
Implementing new technologies in publishing: enhanced printed books
}

\author{
I. Hebrang Grgić* F. Grgić ** and I. Despot*** \\ ${ }^{*}$ Department of Information and Communication Sciences, Faculty of Humanities and Social Sciences, University of \\ Zagreb, Zagreb, Croatia \\ ** student, Faculty of Electrical Engineering and Computing, University of Zagreb, Zagreb, Croatia \\ ${ }^{* * *}$ student, Postgraduate Doctoral Study, Department of Information Sciences, University of Zadar, Zadar, Croatia \\ ihgrgic@ffzg.hr
}

\begin{abstract}
Although reading e-books is becoming more popular, printed books are still dominant medium in the publishing industry. This paper describes an experimental project that implements new technologies in printed textbook publishing. A textbook for a university course was published and its content was enriched with three innovative possibilities that include usage of tablets, smartphones or personal computers. $Q R$ codes are printed in the book in order to extend content by linking the reader to verified internet sources. In addition, web application was developed to help in the learning process - the application is a quiz composed of ten one-choice questions for each book chapter (with 250 questions in the database that will be upgraded periodically). Prior to publication, the application was tested and the results showed that students are ready to accept new ways of learning. The application is a single-page application that executes its logic on client-side and is written mostly in vanilla JavaScript. Besides QR codes and web application, social networking is used to accomplish interaction between readers, author and publisher. Usage of social networks and application converts a printed book into an integrating resource.
\end{abstract}

Keywords - application; e-learning; m-learning; publishing; social networking sites; text books

\section{INTRODUCTION}

Printed books are still dominant medium in the publishing industry. However, there are many possibilities of enhancing printed books by connecting them with electronic environment. Those possibilities can improve learning at all levels of education. In the centre of our interest are university textbooks. An experimental project will be described in order to analyse possibilities in small markets such as Croatian: a textbook in Croatian language was published and its content was enriched by using QR (quick response) codes, web application and social networking sites (Facebook and Twitter).

\section{E-LEARNING AND M-LEARNING IN HIGHER EDUCATION: LITERATURE OVERVIEW}

E-learning, as well as new concepts like e-books and etextbooks, has been changing and supplementing its meaning with the development of new technologies thus making it difficult to define it. The e-book was originally considered a reader or a software, and today's definition of this term is focused on content. Authors Vassiliou and Rowley [1] point out the dynamic nature of this concept as well as the ongoing quest for e-book definition in line with technological achievements.

Explaining relation between distance learning (dlearning), electronic learning (e-learning) and mobile learning (m-learning), Gregoriev, Georgieva and Smrikarov [2] place e-learning as a subset of d-learning; and m-learning as a subset of e-learning, as shown in Figure 1.

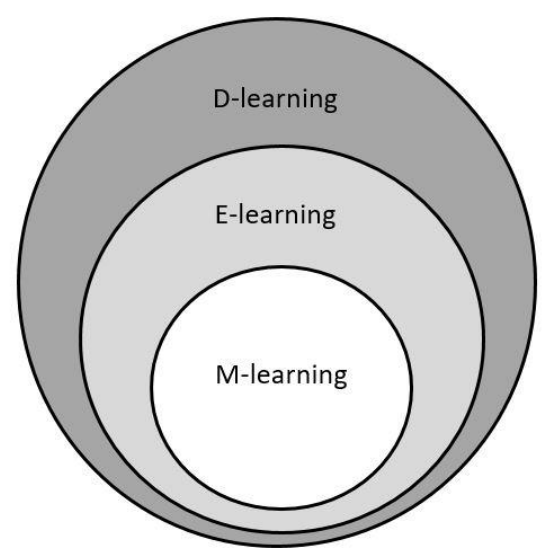

Figure 1. E-learning and m-learning as parts of d-learning [1]

The term e-learning, in theory, has different interpretations. The prefix ' $e$ ' in the e-learning can refer to electronic learning or to learning enriched with technology (technology enhanced learning). Borgman [3] cites a simple definition which is appropriate for the purposes of this paper where e-learning is considered to be learning enhanced with the help of information and 
communication technologies. Moore, Dickson-Deane, and Galyen [4] state that e-learning often overlaps with terms regarding distance learning or online learning. They emphasize that the design of a learning environment depends on the learning goal, target audience, access (physical, virtual and/or both) and the type of content. Authors of textbooks and publishers participating in the creation of educational content should be familiar with the good practice of applying educational technologies in the learning environment. The development of digital technology and Web 2.0 tools brings new guidelines in elearning development such as collaborative learning and ever-greater interactivity of content. The popularity of using social networks in education, the rapid sharing of content and its display on all devices at any time leads to changes, and e-learning is becoming more and more mobile learning or m-learning.

Mobile wireless personal devices are transforming many segments of human society, including discourse of knowledge and enabling new forms of learning [5]. Mlearning happens when the learner is not at a fixed location, or learning connected whit the advantages offered by mobile technologies [6]. That means that $\mathrm{M}$ does not stand only for mobile technologies but also for mobility - it overcomes physical barriers and can be practice regardless of place and time [7]. Crompton [8] defines m-learning as "learning across multiple contexts, through social and content interactions, using personal electronic devices“. Sharples [9] explains m-learning as the process of learning through exploration and interaction amongst people and technologies. Portable technology is used to support curriculum learning in the classroom and personal mobile devices are used for learning on the move.

Some of the m-learning principles, according to Heick [10], are access (to content, peers, experts...), transparency (e.g. through social networking platforms), play (as an important characteristic of progressive learning), self-actuation, diversity and authenticity (that is impossible to reproduce in a classroom).

Technology development allows textbook authors to use text and images as well as the integration of other digital content such as sound, video and animation thus enriching the learning content with technology. At the turning point between print and digital educational content, or traditional printed textbooks and digital textbooks enriched with digital educational content, the emergence of hybrid products offers the benefits of both technologies, their comparisons and the application of the most effective educational technologies in educational processes.

The printed book is still dominant in education but new technologies are emerging and their introduction needs to be experimented with. Technology should be used in publishing to add value to the publishing product depending on the publishing field and content type [11]. Tian and Martin [12] see e-learning as an opportunity for educational publishing which, with its experience in the textbook production, can contribute to a higher quality elearning environment that always includes technological companies, institutions, technology designers and other. The leader of a great research project Network Generation: Strategic Research, Don Tapscott [13] in his book, Grown Up Digital, tells teachers in one of the strategies for the digital age:

\section{Don't throw technology into the classroom \\ and hope for good things. Focus on the \\ change in pedagogy, not the technology.}

Ever since 2002, a major research project, the NMC Horizon Report has foreseen the introduction of technology in education, and lists trends, challenges and technologies from various industries that can be used to enrich learning. The report states that technology alone cannot transform education, but digital tools and platforms can accelerate teaching processes [14]. According to Garrison [15] there are no simple rules for good e-learning but what can help us is the answer to the question of what e-learning can do and the traditional teaching methods cannot.

Trying to use the best of both worlds to teach, the authors discover the potential of new visual technologies among which the Augmented Reality (AR) technology stands out. Lee [16] highlights the great potential of AR technology that "combines real world with augmented information in interactively seamless ways."

Dachselt and Al-Saiegh [17] point to many different attempts and examples in finding solutions for linking printed books and digital content. They suggest the concept of Projective Augmented Books (PAB), which "does not require fixed locations and expensive hardware and can be used almost everywhere and also combined well-known pen interaction as a natural mode of interaction with a visual augmentation of real surfaces."

Learning with the help of education books with augmented reality records good results with complex 3D concepts as well as in teaching students with difficulties on mastering curricula with textually dominant teaching materials [18].

This paper presents a hybrid-publishing product consisting of a printed textbook, additional digital content accessed by QR technology, a web application and content on social networks. The combination of educational technologies in shaping a hybrid-publishing product aims to provide more efficient and effective learning. Recognizing of the needs of students for learning that is more flexible and in the spirit of good teaching, students will meet well-known technologies; the well-known technology will be used in an innovative way, and alternative solutions will be offered for new learning practices that are unknown to some students or still unavailable.

The aim of this project compared to other AR integration concepts in education is the use of a combination of new technologies in order to provide students with a choice in access to content and more opportunities to master the required material. 


\section{REALISATION OF THE PROJECT}

The production of book Short History of Libraries and Publishers: with Codes and an Application began in January 2017 when the manuscript and the application were sent to the University of Zagreb Committee for University Textbooks [15]. The committee sent the manuscript to two peer reviewers and in May 2017 the manuscript was accepted to be published in the University of Zagreb Textbooks Series (Manualia Universitatis studiorum Zagrebiensis). Publisher Naklada Ljevak from Zagreb included publication of the book into their plan, and in October 2017 Ministry of Science and Education of the Republic of Croatia decided to support financially publication of the book.

Plan was to publish the book in printed format, and to add three extensions to broaden the book content: QR codes were prepared to be printed in the book; web application was developed and tested; and social networking sites (SNSs) for the book were opened on Facebook and Twitter.

The book, the application and the content on SNSs are in Croatian language. Content that is available on some of the QR codes is in other languages (English, French, German and Spanish).

\section{A. QR codes}

QR code is two-dimensional machine-readable barcode. QR codes can be read by machine-vision systems that consist of optical laser scanners or cameras, as well as of barcode-interpreting software [16]. Figure 2 represents an example of a $\mathrm{QR}$ code (in this case, the code is link to the book web page on the publisher's web site).

The codes used in the book are supposed to be read by smartphones. The codes link the book to relevant content on the Internet. There are $139 \mathrm{QR}$ codes printed in the book (95 printed in the text to illustrate it, and 44 printed at the end of the book, as additional codes).

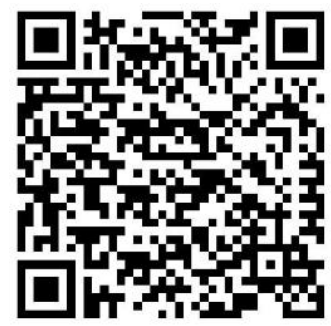

Figure 2. QR code, webpage of the book,

http://www.ljevak.hr/knjige/knjiga-21996-kratka-povijest-knjiznica-inakladnika

There are two main limitations of using QR codes in printed books - (1) the websites they are linked to can become unavailable and (2) readers of the printed book could not be able to use smartphones (either because they do not own one, or because they do not know how to use QR codes). To minimise the first limitation, only links to reliable sources were chosen, e.g. websites of libraries, of universities and publishers. The links are mostly to digital collections (e.g. Digital Incunabula Collection of Spanish National Library) or specific items in digital collections (e.g. digitized Gutenberg's Bible on the website of the British Library). Those institutions usually maintain their websites and care about long-term preservation of their digital collections, but some links could still become unavailable. In case of any change, readers will be able to find information about new links on the SNSs.

In order to ensure long-term availability of the sources behind the QR codes, publisher plans to maintain the list of URLs on the publisher's web site, i.e. on the webpage that is available in the book via $\mathrm{QR}$ code.

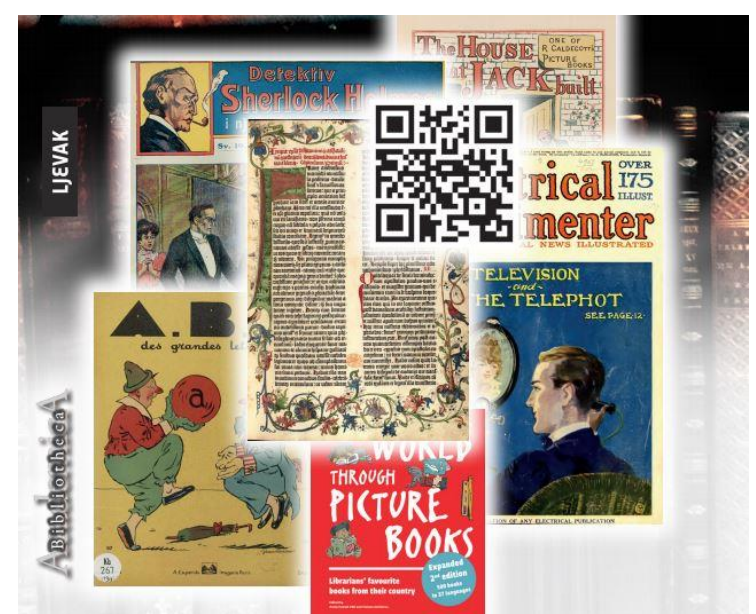

Figure 3. Part of the book cover, a QR code that links to the application is incorporated (www.povijestknjige.net), design by Luka Gusić

The second limitation of using QR codes is solved in the printed book in two ways. In the introduction chapter of the book the concept of QR codes is explained. If a reader does not own a smartphone, he can find all the links at the end of the book (in the List of codes), so he could access them through an Internet browser. One code is incorporated in the book-cover design. The code is link to the application (Figure 3).

\section{B. The application}

Web application was developed to help students and all the other users in learning process - the application is a quiz composed of ten one-choice questions for each book chapter. There are 8 chapters in the book and 250 questions in the database. Reader (user) choose the chapter (by clicking on the chapter icon) and starts answering the questions that are randomly chosen from the database. Figure 4 shows icon for the fifth chapter (The Sixteenth Century). Plan is to upgrade the database with new questions. All the questions are based on the content of the book.

The application is a single-page application that is written mostly in vanilla JavaScript. It can be easily used on any device thanks to the responsive design. Whether that's a mobile phone, a laptop or a desktop computer, the application adjusts itself to fit the screen size of the device it is running on.

All the logic is executed on the client machine in a way that once the application is loaded, it no longer needs 
to contact the server. That kind of approach enables more fluid performance.

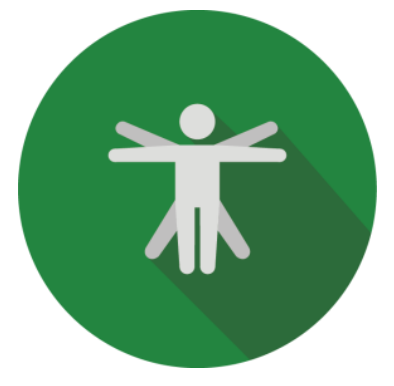

Figure 4. Icon from the application for the fifth chapter of the book, design by Fran Grgić

The icons used in the application are printed in the book at the end of each chapter. The application is available on the web ${ }^{1}$ free of charge and can be used by anyone, even if they do not own or have not read the book.

Prior to publication, the application was tested. A link to the beta version was sent to all the students who have finished the course History of Book and Libraries at the undergraduate Study of Information Sciences at the Department of Information and Communication Sciences, Faculty of Humanities and Social Sciences, University of Zagreb. The book is a textbook for the course.

In December 2017 and January 2018, they were asked to answer a six-question questionnaire to evaluate the application. Five questions had rating scales ( $1-$ poor; 2 - satisfactory; 3 - good; 4 - very good; 5 - excellent), and one question was open for commentaries. By the end of January 2018, 34 out of 40 students answered the questions.

The students' evaluation showed that they are extremely content with four parameters - the access to application, application design, content and clarity of the questions, and content and clarity of the offered answers. The average marks for the four parameters were all above 4.6. Students were also satisfied with the fifth parameter (the estimated time to complete the questions), but the parameter had the lowest average mark (3.18). The short time to answer the questions was the only problem discovered by the conducted user test. The results for all the parameters are in the Table 1 .

The open question was optional and the comments illustrate results from Table 1. Some of the comments were:

"Excellent idea and realisation!"

"We definitely need more time for answering the questions."

"The design is very nice, but there is not enough time to answer the questions."

"The application is excellent."

"Very good tool for learning."

Based on the results, the application was modified and in final version more time for answers is allowed.

\footnotetext{
${ }^{1}$ www.povijestknjige.net
}

TABLE I. Evaluation Results for Beta Version oF tHE APPLICATION

\begin{tabular}{|l|l|}
\hline Parameter & $\begin{array}{l}\text { Average mark } \\
\text { (on 1 - 5 scale) }\end{array}$ \\
\hline Content and clarity of offered answers & 4.91 \\
\hline Access to the application & 4.88 \\
\hline Content and clarity of questions & 4.79 \\
\hline Application design & 4.68 \\
\hline Estimated time to complete the questions & 3.18 \\
\hline
\end{tabular}

Other than the web application, future plans include developing Android and iOS native applications and deploying them to their respective application distribution platforms.

Moreover, introducing a score board, hall of fame, progress badges, etc. is the next big thing to implement since gamification has repeatedly proven itself a very powerful tool in e and m-learning.

\section{Social Networking Sites}

Facebook page ${ }^{2}$ and Twitter profile ${ }^{3}$ were opened to extend the content of the book. QR codes and links to access the pages are published in the book.

At the moment of publishing of the book (January 2018), the timeline of production was available on the social networking sites. Figure 5 shows a Facebook post, and Figure 6 shows a Tweet about some phases of the book production. It is planned to encourage interaction with the readers once the book is published, but everyone could interact on SNSs, even if they do not own, or have not read the book. New links and information that are connected to the content of the book will be published on SNSs. The content on SNSs will transform the printed book into an integrating resource - a resource that is changed by means of updates that do not remain discrete and are integrated into the whole [17].
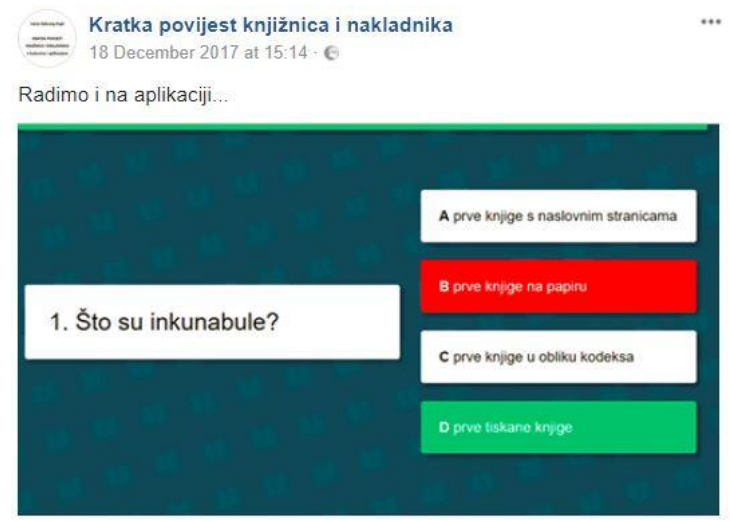

Figure 5. Facebook post on the page Kratka povijest knjižnica $i$ nakladnika (Short History of Libraries and Publishers) - insight into a beta version of application, $18^{\text {th }}$ December 2017

\footnotetext{
${ }^{2}$ https://www.facebook.com/pg/knjiznicenakladnici/posts

${ }^{3}$ https://twitter.com/pov_knjiz_nakl
} 


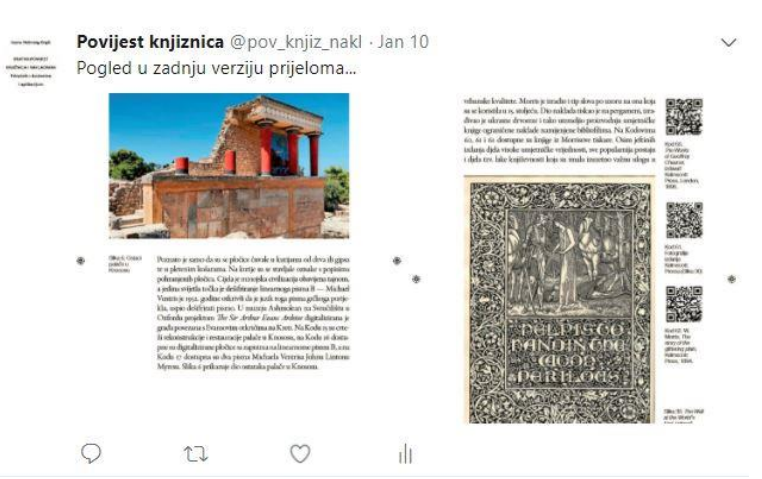

Figure 6 . Tweet from $10^{\text {th }}$ January 2018 - the insight into a final layout

\section{CONLUSION}

New technologies are entering the discourse of learning and teaching at all education levels, from primary schools, to higher education and lifelong learning. At the same time, printed books are still dominant way of communicating in science and education. Hybrid solutions in publishing industry include printed books along with the usage of new technologies, e.g. online courses, social networking sites, web or mobile applications.

The project described in the paper is a pioneer project in Croatian publishing industry. Short History of Libraries and Publishers: with Codes and an Application is the first academic book in Croatian language that uses QR codes, application and SNSs. Pre-evaluation showed that students are ready to accept new ways of learning. More evaluation is planned in the future - new questionnaires about the book will be published on SNSs every year to help enhance the changeable part of the book (the application and the presence on Facebook and Twitter).

In this case, printed book is enhanced and thus becomes a hybrid integrating resource, resource that is partly changeable (not the printed book itself, but expanded content that can be updated in web application and on social networking sites).

\section{REFERENCES}

[1] M. Vassiliou and J. Rowley. "Progressing the definition of 'ebook'," Library Hi Tech, 26(3), 2008. 355-368.

[2] T. Gregoriev, E. Gregorieva, and A. Smrikarov, "M-learning: a new stage of e-learning," in CompSysTech '04: proceedings of the 5 th international conference on computer systems and technologies. Rousse, Bulgaria, 2004, pp. 1-5. doi $10.1145 / 1050330.1050437$
[3] C. L. Borgman. "Scholarship in the digital age: information, infrastructure, and the Internet," Cambridge; London: MIT press, 2007

[4] J. L. Moore, C. Dickson-Deane, and K. Galyen. "E-learning, online learning, and distance learning environments: are they the same?," The Internet and Higher Education, vol. 14, no. 2, pp. 129-135, 2011. doi: 0.1016/j.iheduc.2010.10.001

[5] J. Traxler, "Current state of mobile learning," Mobile Learning, vol. 1, pp. 9-24, 2009.

[6] C. O’Malley, G. Vavoula, Jp. Glew, J. Taylor, M. Sharples, P. Lefrere, P. Lonsdale, L. Naismith, and J. Waycott. "Guidelines for learning/teaching/tutoring in a mobile environment. MOBIlearn project report: D4.1. 2005. Available at https://hal.archivesouvertes.fr/hal-00696244/document

[7] A. Kukulska-Hulme. "Mobile learning as a catalyst for change," Open Learning, vol. 25, no. 3, pp. 181-185, November 2010. Doi: 10.1080/02680513.2010.511945

[8] H. Crompton. "A historical overview of mobile learning: toward learner-centered education," in Handbook of mobile learning. Z. L. Berge and L. Y. Muilenburg, Eds. Florence: Routledge, 2013, pp. 3-14

[9] M. Sharples. "Mobile learning: research, practice and challenges," Distance Education in China, vol. 5, no. 3, 2013, pp. 5-11. Avaliable at: http://oro.open.ac.uk/37510/2/sharples.pdf

[10] T. Heick. "12 principles of mobile learning," Teachthought, 27 January 2018. Available at: https://www.teachthought.com/learning/12-principles-of-mobilelearning/

[11] J. B. Thompson. "Books in the digital age: the transformation of academic and higher education publishing in Britain and the United States," Cambridge: Polity Press, 2005

[12] X. Tian, and B. Martin. "Value chain adjustments in educational publishing," Publishing Research Quarterly, vol. 29, no. 1, pp. 1225, 2013. doi: 10.1007/s12109-012-9303-2

[13] D. Tapscott. “Odrasti digitalno," Zagreb: Školska knjiga, 2010

[14] S. A. Becker, M. Cummini, A. Davis, A. Freeman, C. G. Hall, and V. Ananthanarayanan. "NMC horizon report: 2017 higher education edition," The New Media Consortium, pp. 1-60, 2017. Avaliable at: http://cdn.nmc.org/media/2017-nmc-horizon-reporthe-EN.pdf

[15] D. R. Garrison. "E-learning in the $21^{\text {st }}$ century: a framework for research and practice," New York: Taylor \& Francis, 2011

[16] K. Lee. "Augmented reality in education and training," TechTrends, 56(2), 2012. 13-21

[17] R. Dachselt and S. Al-Saiegh. "Interacting with printed books using digital pens and smart mobile projection," Proc. of the Workshop on Mobile and Personal Projection (MP2)@ ACM CHI. Vol. 11. 2011

[18] D. Andreas, L. Walker, H. Horner and D. Bentall. "Creating interactive physics education books with augmented reality," In: Proceedings of the 24th Australian computer-human interaction conference. ACM, 2012. p. 107-114

[19] I. Hebrang Grgić. "Kratka povijest knjižnica i nakladnika: s kodovima i aplikacijom," Zagreb: Naklada Ljevak, 2018

[20] DENSO ADC. QR code essentials, 2011. Available at: http://www.nacs.org/LinkClick.aspx?fileticket=D1FpVAvvJuo\%3 D\&tabid=1426\&mid $=4802$

[21] ISBD: international standard bibliographic description: consolidated edition. Berlin; Boston: De Gruyter Saur, 2011 